\title{
Norepinephrine Turnover in the Left Ventricle of Subtotally Nephrectomized Rats
}

\author{
L. NALOS ${ }^{1,2}$, J. ŠVÍGLEROVÁ ${ }^{1,2}$, D. RAJDL ${ }^{3}$, J. JEDLIČKA $^{1,2}$, J. DEJMEK $^{2,4}$, \\ M. ŠTENGL ${ }^{1,2}$, J. KUNCOVÁ ${ }^{1,2}$
}

${ }^{1}$ Institute of Physiology, Faculty of Medicine in Plzeň, Charles University, Plzeň, Czech Republic, ${ }^{2}$ Biomedical Centre, Faculty of Medicine in Plzeň, Charles University, Plzeň, Czech Republic, ${ }^{3}$ Institute of Clinical Biochemistry and Hematology, Faculty of Medicine in Plzeň and Teaching Hospital, Plzeň, Czech Republic, ${ }^{4}$ Institute of Biophysics, Faculty of Medicine in Plzeň, Charles University, Plzeň, Czech Republic

Received March 21, 2019

Accepted October 4, 2019

\begin{abstract}
Summary
Increased activity of the sympathetic nervous system (SNS) has been proposed as a risk factor for increased cardiovascular mortality in patients with chronic kidney disease (CKD). Information on the activity of cardiac sympathetic innervation is non-homogeneous and incomplete. The aim of our study was to evaluate the tonic effect of SNS on heart rate, norepinephrine turnover and direct and indirect effects of norepinephrine in left ventricles of subtotally nephrectomized rats (SNX) in comparison with sham-operated animals (SHAM). Renal failure was verified by measuring serum creatinine and urea levels. SNX rats developed increased heart rates and blood pressure (BP). The increase in heart rate was not caused by sympathetic overactivity as the negative chronotropic effect of metipranolol did not differ between the SNX and SHAM animals. The positive inotropic effects of norepinephrine and tyramine on papillary muscle were not significantly different. Norepinephrine turnover was measured after the administration of tyrosine hydroxylase inhibitor, pargyline, tyramine, desipramine, and $\mathrm{KCl}$ induced depolarization. The absolute amount of released norepinephrine was comparable in both groups despite a significantly decreased norepinephrine concentration in the cardiac tissue of the SNX rats. We conclude that CKD associated with renal denervation in rats led to adaptive changes characterized by an increased reuptake and intracellular norepinephrine turnover which maintained normal reactivity of the heart to sympathetic stimulation.
\end{abstract}

\author{
Key words \\ Norepinephrine - Chronic kidney disease - Sympathetic \\ overactivity $\bullet$ Heart

\section{Corresponding author} \\ J. Kuncová, Institute of Physiology, Faculty of Medicine in Plzeň, \\ Charles University, Alej Svobody 76, 32300 Plzeň, Czech \\ Republic. E-mail: jitka.kuncova@lfp.cuni.cz
}

\section{Introduction}

The incidence of chronic kidney disease (CKD) is increasing, and it is associated with poor prognosis, poor health outcomes, and very high health care costs (Coresh et al. 2007). Over $50 \%$ of deaths in renal failure patients are due to cardiovascular causes (Herzog et al. 2011). Sympathetic hyperactivity is considered an independent risk factor of cardiovascular death in patients with CKD (Kaur et al. 2017). Patients with CKD have elevated noradrenaline concentrations in plasma (Rahman et al. 1993), increased resting activity of sympathetic nerves (supplying the vessels in skeletal muscles or skin) (Converse et al. 1992, Ligtenberg et al. 1999), or altered sympathovagal balance (estimated from the ratio of low-frequency power to high-frequency power obtained by power spectral analysis of the heart rate variability) (Giordano et al. 2001).

Several studies on humans and animals with various models of CKD have indicated that renal sensory 
denervation could abrogate to considerable extent sympathetic nervous system hyperactivity, symptoms of CKD and associated cardiovascular diseases (Campese et al. 1995, Sata and Schlaich 2016).

The aim of the present study was to verify and extend our previous observations of missing sympathetic overactivity in a rat model of subtotal (5/6) nephrectomy (Kuncova et al. 2009, Sviglerova et al. 2010) in relation to markers of sympathetic and sensory innervation of the remnant kidney. Ten weeks after surgery, we determined the tonic influence of the sympathetic innervation on heart rate, plasma norepinephrine levels, norepinephrine and neuropeptide Y (NPY) concentrations in the heart compartments, turnover and release of norepinephrine in the left ventricle, and effect of norepinephrine and tyramine (norepinephrine releaser) on the contractility of the left ventricular papillary muscle. Additionally, the concentration of norepinephrine, NPY, and calcitonin gene-related peptide (CGRP) were analyzed in the remnant kidney.

\section{Methods}

\section{Rat model of chronic kidney disease}

All the experiments were performed in accordance with the European Directive for the Protection of Vertebrate Animals Used for Experimental and Other Scientific Purposes (86/609/EU), the relevant Guidelines of the Czech Ministry of Agriculture for scientific experimentation on animals and were approved by the University Committee for Experiments on Laboratory Animals (Charles University, Czech Republic).

This study was conducted in 4-months old, male Wistar rats (Velaz, Prague, Czech Republic) randomly allocated to subtotal nephrectomy (SNX, n=50) and sham operation (SHAM; n=50) groups. First, anesthesia was administered with intraperitoneal sodium pentobarbital $(100 \mathrm{mg} / \mathrm{kg})$, and then a surgical 5/6 renal mass reduction in 2 stages or sham operation was performed as described previously (Sviglerova et al. 2010). Before surgery and 10 weeks after surgery, creatinine concentrations in serum and urine, and urea concentration in serum were measured using a routine autoanalyzer system (Olympus AU 640, Mishima, Japan). At the same time the animals were placed in metabolic cages and 24-hour samples of urine were collected. The glomerular filtration rate (GFR) was estimated by creatinine clearance and the animals were sacrificed 10 weeks after surgery.

\section{Blood pressure}

Systolic and diastolic blood pressure (BP) was measured 10 weeks after the sham-operation or subtotal nephrectomy by the tail-cuff method using a Rat Tail Blood Sytem (RTBP) apparatus (Kent Scientific Corporation, Torrington, CT, USA).

Resting heart rate and chronotropic response to metipranolol after atropine

The heart rate of the rats in the SHAM and SNX groups were measured 10 weeks after surgery using a chamber with floor electrodes connected to an electrocardiograph (EKG Seiva Praktik, Seiva, Prague, Czech Republic; Kuncova et al. 2009). After $20 \mathrm{~min}$ adaptation, the resting heart rate was measured 4 times with 1-minute intervals. Atropine, a muscarinic receptor antagonist (atropine sulfate; $4 \mathrm{mg} / \mathrm{kg}$, s.c.) was administered followed by metipranolol, a $\beta$-adrenergic receptor antagonist (Hoechst-Biotika, Martin, Slovak Republic; $2 \mathrm{mg} / \mathrm{kg}$ of body weight, s.c.) to estimate the tonic influence of cardiac sympathetic innervation on the heart rate which was measured 20 min after the last drug administration. The individual values mentioned in the results are the average of 4 measurements.

\section{Norepinephrine turnover in the left ventricle}

Norepinephrine turnover in the left ventricles was estimated on the basis of its decreasing tissue concentrations after in vivo inhibition of tyrosine hydroxylase. The animals in the SHAM and SNX groups were divided into three subgroups. Baseline norepinephrine concentrations in the left ventricles were determined at time 0 (Groups SHAM0 and SNX0 groups, $\mathrm{n}=6$ per group). The animals from groups SHAM4 and SNX4 ( $n=6$ per group) received $\alpha$-methyl-DL-p-tyrosine methyl ester (AMPT; $200 \mathrm{mg} / \mathrm{kg}$ intraperitoneal), a tyrosine hydroxylase inhibitor, at time 0 and they were killed $4 \mathrm{~h}$ after the drug administration. The SHAM8 and SNX8 rats ( $n=6$ per group) were administered AMPT at times 0 and $4 \mathrm{~h}(200 \mathrm{mg} / \mathrm{kg}$ and $100 \mathrm{mg} / \mathrm{kg}$, respectively) and were killed at $8 \mathrm{~h}$. The free walls of the left ventricles were harvested, frozen on dry ice, weighed, and used to determine norepinephrine tissue levels.

\section{Superfusion experiments I and II}

Two types of superfusion experiments were performed at $37^{\circ} \mathrm{C}$. In the first set of experiments, the free walls of the left ventricles were dissected from the decapitated SHAM and SNX rats ( $\mathrm{n}=3$ per group), sliced 
(approx. 100-200 mg of tissue), pooled, mixed, and then transferred into twelve $0.5 \mathrm{ml}$ perfusion chambers superfused in parallel with oxygenated $\left(95 \% \mathrm{O}_{2}-5 \%\right.$ $\mathrm{CO}_{2}$ ) Krebs-Henseleit (KH) solution (composition in mmol/l: $\mathrm{NaCl} 113, \mathrm{NaHCO}_{3} 25, \mathrm{KCl} 4.75, \mathrm{CaCl}_{2} 2.5$, $\mathrm{MgSO}_{4}$ 1.19, glucose 11.1, $\mathrm{Na}_{2}$ EDTA 0.029, ascorbic acid 0.289 ). At time 0 , a subsample of the tissue was used to determine norepinephrine concentrations. The tissues were then superfused at a rate of $0.05 \mathrm{ml} / \mathrm{min}$ with $\mathrm{KH}$ solution without any addition (nil), $\mathrm{KH}$ solution containing pargyline $\left(10^{-6} \mathrm{~mol} / \mathrm{l}\right)$, pargyline with desipramine (both $10^{-6} \mathrm{~mol} / \mathrm{l}$ ), and pargyline with tyramine (both $10^{-6} \mathrm{~mol} / \mathrm{l}$ ). The tissues were collected at time $3 \mathrm{~h}$. Norepinephrine levels were determined in all the tissue samples after extraction and expressed as percentage of time 0 concentrations.

In the second set of superfusion experiments, the sliced free walls of the left ventricles were placed into $0.5 \mathrm{ml}$ chambers superfused with oxygenated $\mathrm{KH}$ solution or modified depolarizing solution containing $50 \mathrm{mmol} / 1 \mathrm{KCl}(\mathrm{NaCl}$ concentration was accordingly reduced) at a rate of $0.1 \mathrm{ml} / \mathrm{min}$. After an equilibration period of $30 \mathrm{~min}$, three 10-min fractions were collected at $0{ }^{\circ} \mathrm{C}$. Basal release of $\mathrm{NE}$ was measured in fraction 1 , then the $\mathrm{KH}$ solution was changed for the depolarizing fluid, the 10-min fraction 2 was discarded and depolarization-induced stimulated release was measured in the last 10-min fraction 3. The superfusion solutions contained no additions (nil), pargyline with desipramine or pargyline with tyramine (all $10^{-6} \mathrm{~mol} / \mathrm{l}$ ) and were stored at $-75^{\circ} \mathrm{C}$.

Norepinephrine concentrations in the heart, kidney, plasma, and superfusates

Blood was collected on EDTA and centrifuged $\left(1000 \times \mathrm{g}, 4{ }^{\circ} \mathrm{C}, 15 \mathrm{~min}\right)$. The plasma was removed and stored at $-20^{\circ} \mathrm{C}$ for determination of norepinephrine concentration. The hearts and kidneys were rapidly excised. The tissues were rinsed with ice-cold saline, all connective tissue and fat were removed, and the heart was divided into the left atrium with the interatrial septum, right atrium, and free walls of both ventricles. The tissues from the superfusion experiments were blotted dry on filter paper and weighed. Norepinephrine was extracted from the tissue samples by homogenization in 10 volumes of $0.1 \mathrm{~mol} / 1 \mathrm{HCl}$ containing $1 \%$ of ascorbic acid and was subsequently centrifugated $\left(10000 \times \mathrm{g}, 4^{\circ} \mathrm{C}, 20 \mathrm{~min}\right)$. Then the supernatants were diluted to $1: 10$ with distilled water and stored at $-75^{\circ} \mathrm{C}$ and norepinephrine levels were determined using commercial RIA kits (IBL Hamburg, Germany). The norepinephrine concentrations in the superfusates were determined using radioimmunoassay ultrasensitive diagnostic kits (Labor Diagnostika Nord, Nordhorn, Germany).

Extraction of neuropeptide Y (NPY) and calcitonin generelated peptide (CGRP)

The NPY- and CGRP-like material was extracted from frozen, weighed and pulverized heart compartments and kidneys. The tissues were placed in 10 volumes of extraction solution $(0.5 \mathrm{~mol} / 1$ acetic acid and $0.1 \mathrm{~mol} / 1 \mathrm{HCl}$ containing $100 \mu \mathrm{mol} / 1 \mathrm{EDTA}$ and $0.01 \% \quad \mathrm{Na}_{2} \mathrm{~S}_{2} \mathrm{O}_{5}$ for NPY and CGRP extraction, respectively), heated in a water bath at $95^{\circ} \mathrm{C}$ for $15 \mathrm{~min}$, cooled on ice, and homogenized for $30 \mathrm{~s}$ using an UltraTurrax homogenizer. The homogenates were centrifuged $\left(10000 \times \mathrm{g}, 4{ }^{\circ} \mathrm{C}, 20 \mathrm{~min}\right)$ and the supernatants were neutralized with $5 \mathrm{~mol} / 1$ Tris-base and then centrifuged again $\left(5000 \times \mathrm{g}, 4{ }^{\circ} \mathrm{C}, 10 \mathrm{~min}\right)$. The supernatants were stored at $-75^{\circ} \mathrm{C}$ until radioimmunoassay for NPY and CGRP concentration measurements (Phoenix Pharmaceuticals, Belmont, CA, USA) according the manufacturer's instructions.

Inotropic responses to norepinephrine and tyramine in vitro

The left ventricle papillary muscles were dissected and treated as previously described (Sviglerova et al. 2010). After a stabilization period, the steady-state contractions at a stimulation frequency of $1 \mathrm{~Hz}$ were recorded. Norepinephrine $\left(10^{-7}, 10^{-6}, 10^{-5}\right.$, and $\left.10^{-4} \mathrm{~mol} / \mathrm{l}\right)$ and tyramine $\left(10^{-8}, 10^{-7}, 10^{-6}, 10^{-5}\right.$, and $\left.10^{-4} \mathrm{~mol} / \mathrm{l}\right)$ were added gradually to the bath solution and propranolol $\left(10^{-4} \mathrm{~mol} / \mathrm{l}\right)$ was added to last concentration of tyramine. The data were recorded and analyzed using the DiSys, a data acquisition system (Merlin, Czech Republic).

\section{Chemicals}

If not stated otherwise, all the chemicals were purchased from Sigma-Aldrich, Prague, Czech Republic.

\section{Data analysis and statistics}

The results are presented as means $\pm \mathrm{SD}$. The statistical differences were analyzed using a software package, OriginPro 2017 (OriginLab Corporation, Northampton, Massachusetts, USA, 2017). After testing for the normality of distribution and homogeneity of variances, comparisons were made using a Student's 
$t$-test and a repeated-measures ANOVA with a post hoc Tukey test, where appropriate. The results were considered statistically significant if $\mathrm{p}<0.05$.

\section{Results}

\section{Rat model of chronic renal failure}

To verify the development of chronic renal failure, daily urine volume, serum creatinine and urea levels were determined and GFR was calculated. The serum creatinine and urea concentrations were significantly higher and GFR was significantly lower in the SNX group, 10 weeks after surgery. The weight of the renal stump in the SNX rats was significantly higher compared to the weight of the intact kidney in the SHAM ones (Table 1).

\section{Cardiovascular parameters}

Significantly higher heart rates and elevated systolic and diastolic BPs were observed in SNX rats than in the SHAM animals (Table 1). However, the increase in heart rate did not seem to be caused by sympathetic overactivity as the negative chronotropic effect of metipranolol did not differ between the SHAM and SNX animals. To exclude the majority of interfering interactions between the sympathetic and parasympathetic innervation of the heart, the effect of metipranolol was determined after prior administration of atropine. The relative weight of the left ventricle, determined as a ratio of the heart weight to the body weight, suggested left ventricular hypertrophy in the SNX rats (Table 1).

Table 1. Biochemical data, body and kidney weights and selected cardiovascular parameters of sham-operated (SHAM) and subtotally nephrectomized (SNX) rats ten weeks after surgery.

\begin{tabular}{|c|c|c|c|c|}
\hline & SHAM & $\mathbf{n}$ & SNX & $\mathbf{n}$ \\
\hline Serum creatinine ( $\mu$ mol/l) & $49.1 \pm 13.6$ & 8 & $111.0 \pm 25.3 *$ & 8 \\
\hline Serum urea (mmol/l) & $8.02 \pm 2.07$ & 8 & $27.4 \pm 5.9^{*}$ & 8 \\
\hline GFR (ml/min) & $1.54 \pm 0.4$ & 8 & $0.57 \pm 0.12 *$ & 8 \\
\hline Body weight $(g)$ & $453.5 \pm 8.0$ & 20 & $403.2 \pm 7.8^{*}$ & 20 \\
\hline Kidney weight (g) & $1.36 \pm 0.13$ & 20 & $2.09 \pm 0.68^{*}$ & 20 \\
\hline Systolic pressure (mm Hg) & $136 \pm 12$ & 10 & $188 \pm 24 *$ & 10 \\
\hline Diastolic pressure ( $\mathrm{mm} \mathrm{Hg}$ ) & $97 \pm 12$ & 10 & $127 \pm 21 *$ & 10 \\
\hline Resting heart rate $\left(\mathrm{min}^{-1}\right)$ & $345 \pm 26$ & 8 & $389 \pm 22 *$ & 8 \\
\hline Effect of MP after ATR $\left(\mathrm{min}^{-1}\right)$ & $-84 \pm 10$ & 8 & $-73 \pm 9$ & 8 \\
\hline$H W / B W(\%)$ & $0.31 \pm 0.04$ & 20 & $0.39 \pm 0.07^{*}$ & 30 \\
\hline
\end{tabular}

GFR=glomerular filtration rate measured by clearance of creatinine, ${ }^{*}$ significantly different from SHAM $(p<0.05)$, MP=metipranolol, ATR=atropine, HW=heart weight, BW=body weight.

\section{Norepinephrine concentrations in the plasma}

Norepinephrine concentrations in the plasma of SNX rats 10 weeks after surgery were $1.19 \pm 0.21 \mathrm{ng} / \mathrm{ml}$ and did not significantly differ from those measured in the SHAM animals $(1.32 \pm 0.17 \mathrm{ng} / \mathrm{ml})$.

Norepinephrine and NPY concentrations in the heart compartments and norepinephrine turnover in the left ventricle

The tissue levels of norepinephrine and NPY, the sympathetic neurotransmitters, displayed similar trends in all the heart compartments of the SNX rats at week 10 after surgery. Compared to the SHAM rats, they were significantly decreased in the left atria and ventricles, but not in the right heart compartments. Additionally, the extent of reduction of the tissue stores of both neurotransmitters was similar (Fig. 1A, B).

The norepinephrine turnover rate was significantly higher in the left ventricles of the SNX group of rats, since its tissue levels $8 \mathrm{~h}$ after administration of AMPT (a tyrosine hydroxylase inhibitor) were lower in the SNX animals 10 weeks after surgery (Fig. 1C).

\section{Norepinephrine, NPY and CGRP levels in kidneys}

As shown in Figure 2A-C, stumps of kidneys of SNX rats seemed to be nearly totally denervated, as concentrations of norepinephrine and NPY 

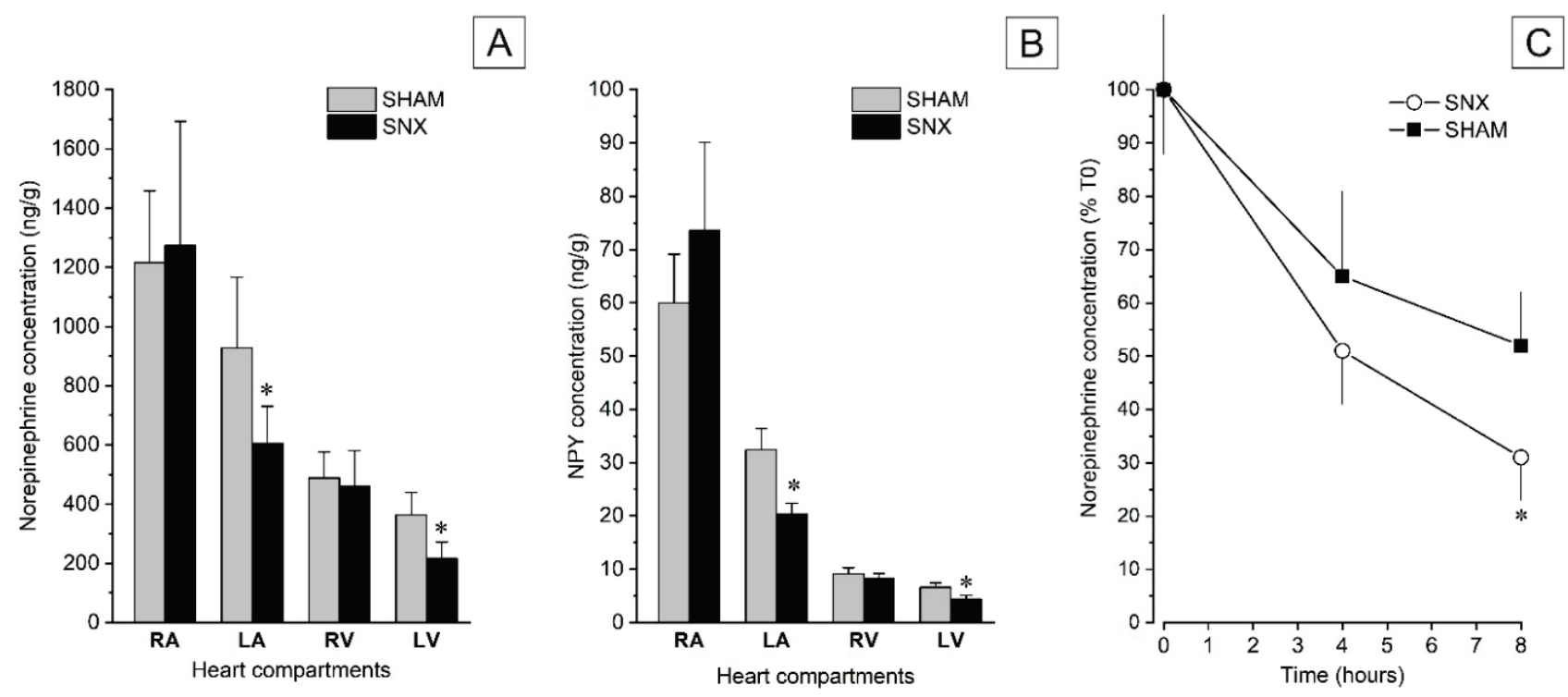

Fig. 1. Norepinephrine (A) and NPY (B) concentrations in the heart compartments of SHAM and SNX rats 10 weeks after surgery. (C) Norepinephrine concentrations in the left ventricles of SHAM and SNX rats 10 weeks after surgery at times 0 , and 4 and $8 \mathrm{~h}$ after administration of tyrosine hydroxylase inhibitor AMPT expressed as percentage of time 0 levels; ${ }^{*}$ significantly different from the respective SHAM value $(p<0.05)$.

A

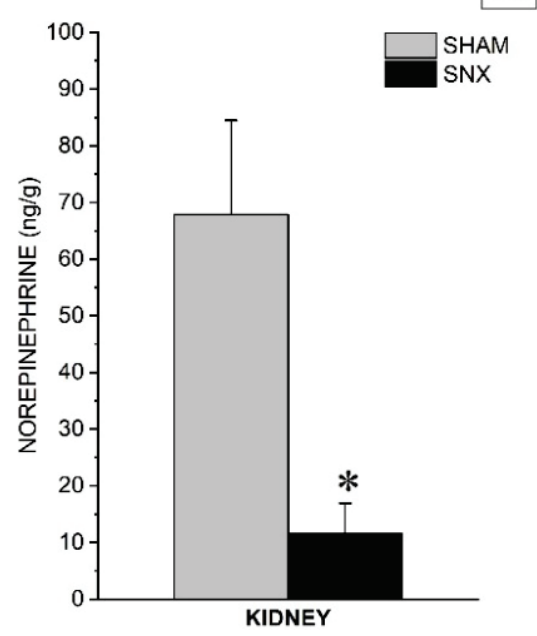

B

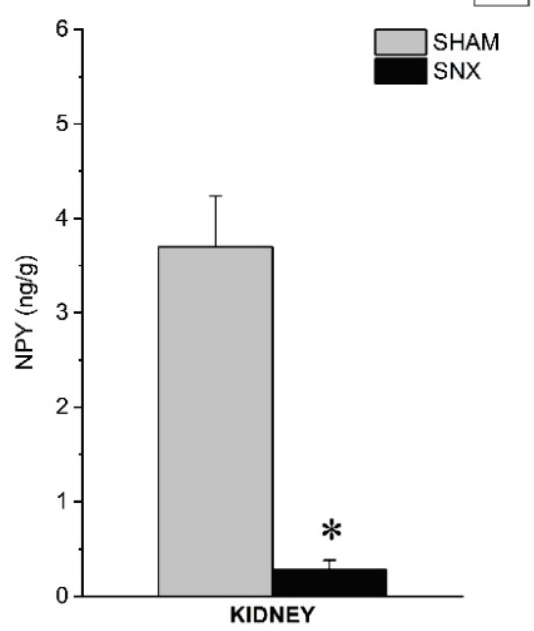

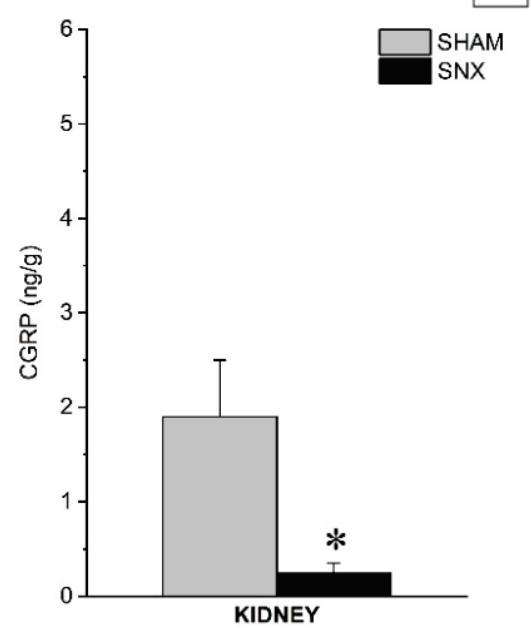

Fig. 2. Norepinephrine (A), NPY (B), and CGRP (C) concentrations in the kidneys of SHAM and SNX rats 10 weeks after surgery; ${ }^{*}$ significantly different from the respective SHAM value $(p<0.05)$.

(two sympathetic neurotransmitters) fell below $10 \%$ of the control values, similar to the CGRP (sensory neurotransmitter) tissue levels.

Effect of pargyline, tyramine, desipramine and depolarization on norepinephrine release from the left ventricles

In the first set of experiments, the tissue levels of norepinephrine were measured after long-lasting superfusion $(3 \mathrm{~h})$ with solutions containing (or not containing) pargyline (alone or in combination with tyramine or desipramine). Surprisingly, the washout of norepinephrine was significantly higher in SHAM left ventricles, where its concentration after 3-hour lasting superfusion with $\mathrm{KH}$ solution resulted in $\sim 50 \%$ reduction of its tissue stores, whereas the SNX tissues still contained $\sim 80 \%$ of the original tissue content (Fig. 3A). Pargyline increased the final concentration of norepinephrine to $\sim 90 \%$ in both sample groups which suggested a lower activity of MAO in SNX left 
ventricles. Both desipramine (inhibitor of norepinephrine uptake) and tyramine (substrate of norepinephrine membrane and vesicular transporters) had more pronounced effects in SNX left ventricles which implied a higher activity of the transporter (Fig. 3A).

In the second set of experiments, basal and $\mathrm{KCl}$-stimulated release of norepinephrine was measured in the superfusates. In all superfusion media, pargyline was added to inhibit norepinephrine degradation by MAO. As shown in Figure 3B, the basal and $\mathrm{KCl}$-stimulated releases of norepinephrine from the SNX and SHAM ventricles were comparable despite a lower tissue content in SNX rats. Desipramine and tyramine had greater effect in the SNX left ventricles.

Inotropic responses to norepinephrine and tyramine in vitro

Compared to the controls, contraction of papillary muscles increased after application of norepinephrine as well as tyramine in a concentration dependent manner in both SHAM and SNX animals (Fig. 4). There were no significant differences in the effect of norepinephrine or tyramine between the SHAM and SNX rats.
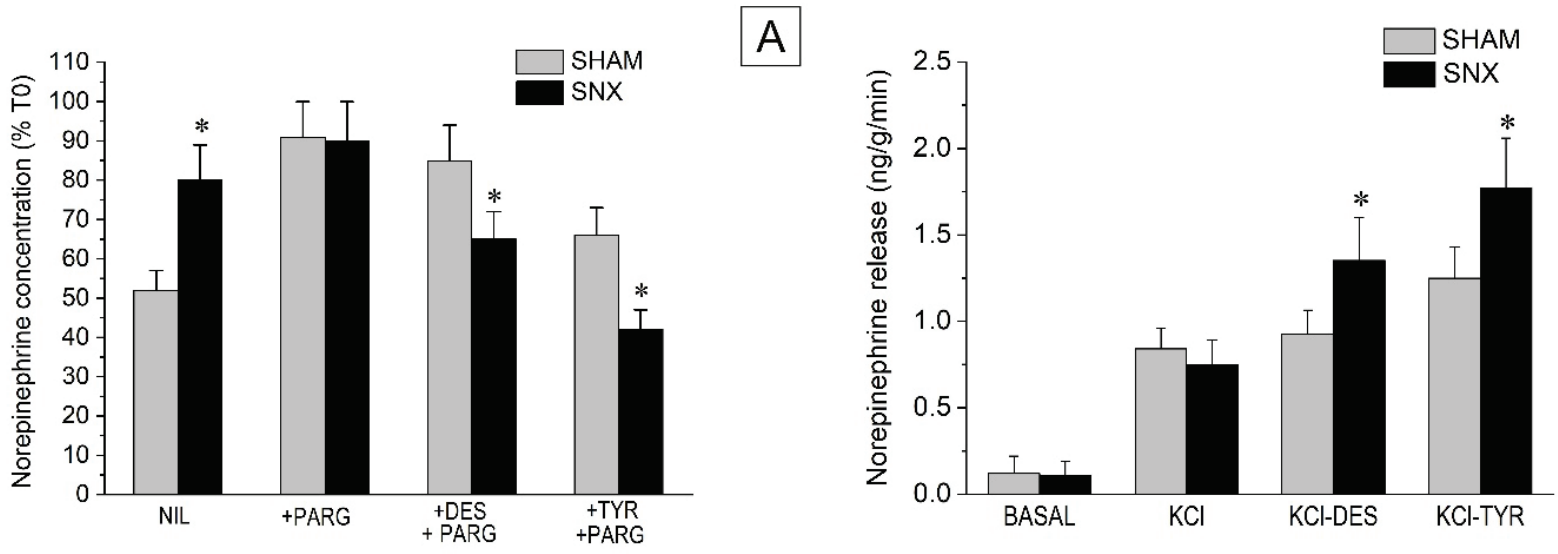

Fig. 3. (A) Concentrations of norepinephrine in sliced free walls of the left ventricles of SHAM and SNX rats 10 weeks after surgery $3 \mathrm{~h}$ after superfusion with $\mathrm{KH}$ solution containing no addition (NIL), pargyline (PARG; $\left.10^{-6} \mathrm{~mol} / \mathrm{l}\right)$, desipramine with pargyline (DES + PARG; both $10^{-6} \mathrm{~mol} / \mathrm{l}$ ), and tyramine with pargyline (TYR + PARG; both $\left.10^{-6} \mathrm{~mol} / \mathrm{l}\right)$. Concentrations are expressed in percentage of time 0 (T0) levels, (B) Concentrations of norepinephrine in the superfusates of the sliced left ventricles under basal conditions (BASAL), after depolarization of tissue by $\mathrm{KCl}(50 \mathrm{mmol} / \mathrm{l})$ in the superfusion fluid $(\mathrm{KCl})$ and after superfusion with depolarizing fluid containing either desipramine (KCl-DES; $\left.10^{-6} \mathrm{~mol} / \mathrm{l}\right)$ or tyramine (KCl-TYR; $\left.10^{-6} \mathrm{~mol} / \mathrm{l}\right)$. All media contained pargyline in a concentration of $10^{-6} \mathrm{~mol} / \mathrm{l}$. ${ }^{*}$ significantly different from the respective SHAM value $(p<0.05)$.
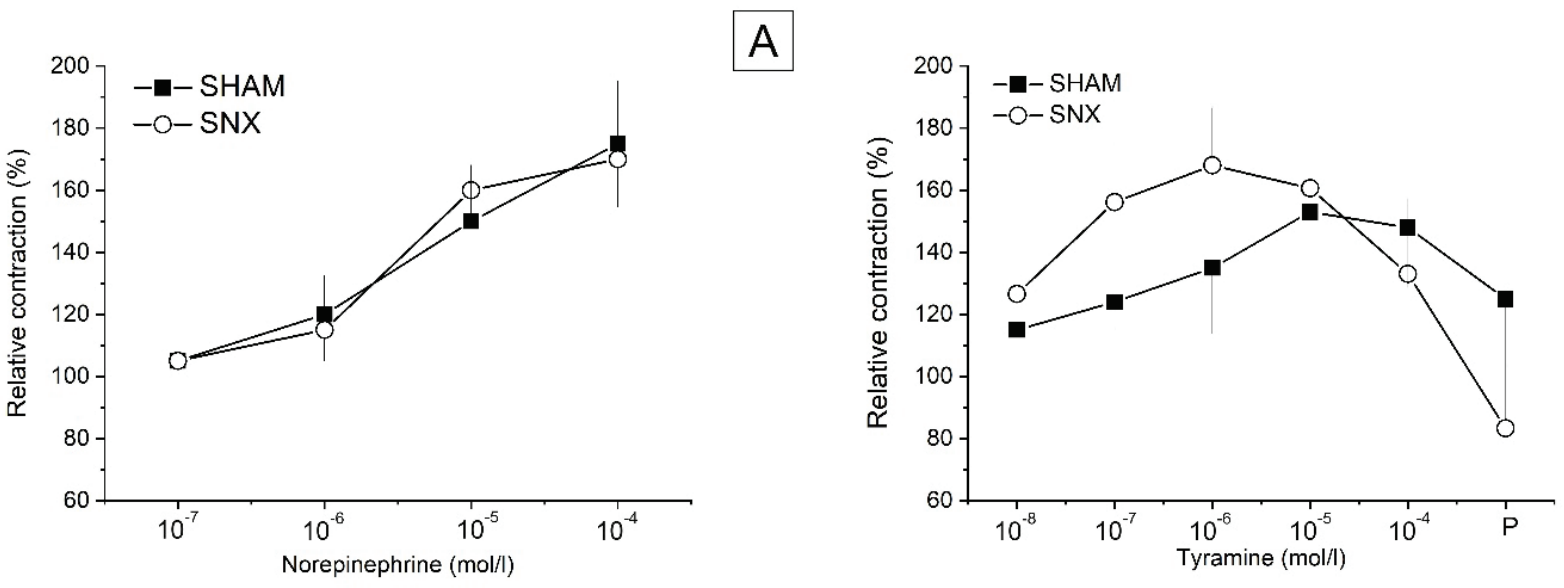

Fig. 4. Relative contraction of the left ventricular papillary muscle after application of norepinephrine (A) and tyramine (B). $100 \%$ was the steady state contraction of the muscle in control solution, P-propranolol. 


\section{Discussion}

The present study analyzes several parameters of cardiac sympathetic innervation in rats subjected to subtotal (5/6) nephrectomy resulting in CKD. The selected animal CKD model is widely used in experiments focusing on pathophysiology of renal diseases and the search for potential therapeutic strategies in renal diseases and accompanying cardiovascular complications (Augustyniak et al. 2010, Vaneckova et al. 2018, Yang et al. 2019). Subtotal nephrectomy is associated with the development of glomerular and tubular hypertrophy, progressive proteinuria and, after a transient phase of severe uremia just after surgery, a relatively long-lasting phase (several weeks to several months) of adaptive, stabilized, but compromised renal function that eventually slowly progresses into end-stage renal disease (Shimamura et al. 1975, Kujal and Vernerová 2008). The adaptive phase of kidney injury induced by subtotal nephrectomy in rats resembles the development of glomerulosclerosis in humans in many aspects (Smeets et al. 2011). Additionally, the rats subjected to renal mass reduction exhibited reduced creatinine clearance, elevated urea plasma concentration and hypertrophy of the remnant kidney stump at week 10 after surgery, the weight of which exceeded the weight of a single kidney from the SHAM animals.

It is well-known that chronic kidney diseases are associated with a number of cardiovascular complications including hypertension, left ventricular hypertrophy, and autonomic neuropathy that may lead to the heart failure, ischemic heart disease, and life-threatening arrhythmias (Singh 2014). The results of our study show that both systolic and diastolic hypertension developed in SNX rats and that it was associated with the left ventricle hypertrophy. Additionally, the resting heart rate was significantly elevated which suggested the possibility of increased sympathetic tone, widely reported in patients with CKD (Rump 2001). However, the negative chronotropic effect of metipranolol after prior administration of atropine did not differ between the SNX and SHAM rats which make this explanation unlikely. Additionally, the concentration of norepinephrine in plasma was not changed by CKD. Although this parameter is considered a subsidiary marker of sympathetic overactivity (Kopin et al. 1998), unchanged plasma levels of norepinephrine do not support the increased sympathetic drive in our model of CKD. Nevertheless, an increased resting heart rate can be explained by decreased parasympathetic activity (Kuncova et al. 2009).

The missing signs of increased sympathetic activity in our study could be related to nearly complete sympathetic and sensory denervation of the remnant kidney. The concentrations of the 2 sympathetic neurotransmitters (norepinephrine and NPY) and the typical marker of sensory nerves (CGRP) in the kidney stump fell to $\sim 10 \%$ of the control values after surgery. The effect of renal denervation in patients is uncertain. On one hand it has been documented that renal denervation in CKD substantially alleviates many symptoms of compromised renal function and might even slow down cardiac hypertrophy ascribed to maladaptation in response to increased sympathetic activity (Ott et al. 2015, Peregrin et al. 2019). On the other hand, no significant difference was found in reduction of systolic $\mathrm{BP}$ in patients with resistant hypertension 6 months after renal-artery denervation as compared to a sham control (Bhatt et al. 2014). In our model, renal denervation was not associated with any improvement of cardiovascular parameters, which is in accordance with others (Tudorancea et al. 2018).

However, on the organ level, interesting changes in norepinephrine concentrations and turnover have been revealed. The tissue concentrations of norepinephrine were significantly lower in the left heart compartments of the SNX rats compared to the SHAM rats. Norepinephrine concentration in tissues may reflect the density of sympathetic innervation and dynamic balance between norepinephrine synthesis, release, uptake, and metabolism (Sedaghat et al. 2017, Brodie et al. 1966). Although the density of adrenergic nerves has not been quantified in this study, similar reduction in tissue levels of NPY and norepinephrine (localized in the sympathetic nerve endings, with substantially different synthesis, intraneuronal localization and metabolism), suggest that the density of sympathetic nerves might be compromised in hypertrophied left ventricles.

The classical method which estimates continuous loss of norepinephrine after its previous synthesis (i.e. its turnover) is based on the in vivo inhibition of tyrosine hydroxylase, the rate-limiting enzyme in catecholamine synthesis (Brodie et al. 1966). Our data suggests that norepinephrine turnover was significantly enhanced in the SNX rats as compared to the controls (since the decline in the transmitter tissue levels after AMPT was more profound 10 weeks after subtotal nephrectomy) which implies an imbalance between 
norepinephrine reuptake and its release and/or metabolism. It is believed that norepinephrine turnover in the mammalian heart is driven mainly by its release in response to increased nerve activity (Patel et al. 2000). However, it should be noted that there is a greater contribution to norepinephrine turnover by an intraneuronal exchange between storage vesicles and cytoplasm via vesicular transporter. A substantial portion of this intraneuronally escaped norepinephrine is metabolized by monoamino oxidase (Eisenhofer et al. 2004), the expression of which has been reported to be elevated in the hearts of SNX rats (Lin et al. 2015).

When the final concentration of norepinephrine in the sliced left ventricles was measured after slow superfusion of the tissue with a solution containing no substances interfering with above mentioned processes, the concentration of norepinephrine was significantly lower in the hearts from the SHAM rats which suggests that the leakage and/or metabolism of the transmitter exceeded its uptake and/or synthesis more than the SNX samples. When pargyline was added into the media, the final concentrations of norepinephrine in the tissue slices were comparable in the left ventricles from both SNX and SHAM rats. In these conditions, desipramine and tyramine had greater effects in the left ventricles from the SNX rats, which suggested an increased norepinephrine transport across cell and vesicular membranes. This finding is in accord with the effect of AMPT on norepinephrine tissue levels that could reflect increased intraneuronal vesicular leakage and sequestration, which is regarded as a measure minimizing the impact of norepinephrine exocytotic release on the requirement for norepinephrine synthesis (Eisenhofer et al. 1998). The direct measurement of norepinephrine release from the sliced tissue verified previous data; the effects of tyramine and desipramine on norepinephrine release from the heart were enhanced by subtotal nephrectomy. Additionally, depolarization $(\mathrm{KCl})$-induced release of norepinephrine was comparable in the samples from both SNX and SHAM rats despite significantly lower norepinephrine concentration in the left ventricles of the SNX rats.
The positive inotropic effect of norepinephrine did not differ between the SNX and SHAM rats, which suggested that the sensitivity of $\beta$-adrenergic receptors to principal sympathetic neurotransmitter was not impaired by CKD. Additionally, tyramine had a comparable effect on the contractility of the left ventricular papillary muscle in SNX and SHAM rats. The administration of propranolol verified that the effect of tyramine was mediated by stimulation of $\beta$-adrenergic receptors. These contractile experiments proved that the SNX left ventricles $\beta$-adrenoceptor responses were preserved despite significantly decreased tissue concentration of norepinephrine.

\section{Conclusions}

The results of the present study show that despite decreased norepinephrine levels in the left ventricle, norepinephrine release was well preserved, probably due to enhanced activity of norepinephrine transporters. Additionally, sensitivity of the left ventricular papillary muscle to norepinephrine and tyramine was not affected. The results of our study suggest that under conditions of renal denervation, norepinephrine balance in the hearts of rats subjected to 5/6 nephrectomy shifts towards increased reuptake and intracellular turnover of norepinephrine that maintains normal reactivity of the heart to sympathetic stimulation.

\section{Conflict of Interest}

There is no conflict of interest.

\section{Acknowledgements}

The study was supported by the Charles University Research Fund (Progres Q39), by the National Sustainability Program I (NPUI) Nr. LO1503 provided by the MEYS CR, project No. CZ.02.1.01/ 0.0/0.0/16_019/0000787 „Fighting INfectious Diseases“, awarded by the MEYS CR, financed from EFRR, and the Specific Student Research Project no. 260394/2017 of the Charles University in Prague.

\section{References}

AUGUSTYNIAK RA, PICKEN MM, LEONARD D, ZHOU XJ, ZHANG W, VICTOR RG: Sympathetic nerves and the progression of chronic kidney disease during 5/6 nephrectomy: studies in sympathectomized rats. Clin Exp Pharmacol Physiol 37: 1440-1681, 2010. 
BHATT DL, KANDZARI DE, O'NEILL WW, D'AGOSTINO R, FLACK JM, KATZEN BT, LEON MB, LIU M, MAURI L, NEGOITA M, COHEN SA, OPARIL S, ROCHA-SINGH K, TOWNSEND RR, BAKRIS GL, SYMPLICITY HTN-3 Investigators: A controlled trial of renal denervation for resistant hypertension. $N$ Engl J Med 370: 1393-1401, 2014.

BRODIE BB, COSTA E, DLABAC A, NEFF NH, SMOOKLER HH: Application of steady state kinetics to the estimation of synthesis rate and turnover time of tissue catecholamines. J Pharmacol Exp Ther 154: 493-498, 1966.

CAMPESE VM, KOGOSOV E, KOSS M: Renal afferent denervation prevents the progression of renal disease in the renal ablation model of chronic renal failure in the rat. Am J Kidney Dis 26: 861-865, 1995.

CAO W, LI A, WANG L, ZHOU Z, SU Z, BIN W, WILCOX CS, HOU FF: A salt-induced reno-cerebral reflex activates renin-angiotensin systems and promotes CKD progression. J Am Soc Nephrol 26: 1619-1633, 2015.

CONVERSE RL JR, JACOBSEN TN, TOTO RD, JOST CM, COSENTINO F, FOUAD-TARAZI F, VICTOR RG: Sympathetic overactivity in patients with chronic renal failure. N Engl J Med 327: 1912-1918, 1992.

CORESH J, SELVIN E, STEVENS LA, MANZI J, KUSEK JW, EGGERS P, VAN LF, LEVEY AS: Prevalence of chronic kidney disease in the United States. JAMA 298: 2038-2047, 2007.

EISENHOFER G, KOPIN IJ, GOLDSTEIN DS: Catecholamine metabolism: a contemporary view with implications for physiology and medicine. Pharmacol Rev 56: 331-349, 2004.

EISENHOFER G, RUNDQVIST B, FRIBERG P: Determinants of cardiac tyrosine hydroxylase activity during exercise-induced sympathetic activation in humans. Am J Physiol 274: R626-R634, 1998.

GIORDANO M, MANZELLA D, PAOLISSO G, CALIENDO A, VARRICCHIO M, GIORDANO C: Differences in heart rate variability parameters during the post-dialytic period in type II diabetic and non-diabetic ESRD patients. Nephrol Dial Transplant 16: 566-573, 2001.

HERZOG CA, ASINGER RW, BERGER AK, CHARYTAN DM, DÍEZ J, HART RG, ECKARDT KU, KASISKE BL, MCCULLOUGH PA, PASSMAN RS, DELOACH SS, PUN PH, RITZ E: Cardiovascular disease in chronic kidney disease. A clinical update from Kidney Disease: Improving Global Outcomes (KDIGO). Kidney Int 80: 572-586, 2011.

KAUR J, YOUNG BE, FADEL PJ: Sympathetic overactivity in chronic kidney disease: consequences and mechanisms. Int J Mol Sci 18: 1682, 2017.

KOPIN IJ, RUNDQVIST B, FRIBERG P, LENDERS J, GOLDSTEIN DS, EISENHOFER G: Different relationships of spillover to release of norepinephrine in human heart, kidneys, and forearm. Am J Physiol 275: R165-R173, 1998.

KUJAL P, VERNEROVÁ Z: Model 5/6 nefrektomie, jako experimentální model chronické renální insuficience a adaptace ledvin na redukci počtu nefronů. Cesk Fysiol 57: 104-109, 2008.

KUNCOVÁ J, ŠVÍGLEROVÁ J, KUMMER W, RAJDL D, CHOTTOVÁ-DVOŘÁKOVÁ M, TONAR Z, NALOS L, ŠTENGL M: Parasympathetic regulation of heart rate in rats after 5/6 nephrectomy is impaired despite functionally intact cardiac vagal innervation. Nephrol Dial Transplant 24: 2362-2370, 2009.

LIGTENBERG G, BLANKESTIJN PJ, OEY PL, KLEIN IH, DIJKHORST-OEI LT, BOOMSMA F, WIENEKE GH, VAN HUFFELEN AC, KOOMANS HA: Reduction of sympathetic hyperactivity by enalapril in patients with chronic renal failure. $N$ Engl J Med 340: 1321-1328, 1999.

LIN YP, YU WC, HSU ME, TSAI HC, LIAO CC, LIN CH: Comparative proteomic analysis of rat left ventricle in a subtotal nephrectomy model. J Chin Med Assoc 78: 218-228, 2015.

OTT C, MAHFOUD F, SCHMID A, TOENNES SW, EWEN S, DITTING T, VEELKEN R, UKENA C, UDER M, BÖHM M, SCHMIEDER RE: Renal denervation preserves renal function in patients with chronic kidney disease and resistant hypertension. J Hypertens 33: 1261-1266, 2015.

PATEL KP, ZHANG K, CARMINES PK: Norepinephrine turnover in peripheral tissues of rats with heart failure. Am J Physiol Regul Integr Comp Physiol 278: R556-R562, 2000.

PEREGRIN JH, NOVOTNÝ J, ROHÁL T, ŠOCHMAN J: Renal sympathetic denervation in resistant arterial hypertension: long term and updated results. Physiol Res 68: 129-133, 2019. 
RAHMAN SN, ABRAHAM WT, VAN PUTTEN VJ, HASBARGEN JA, SCHRIER RW: Increased norepinephrine secretion in patients with the nephrotic syndrome and normal glomerular filtration rates: evidence for primary sympathetic activation. Am J Nephrol 13: 266-270, 1993.

RUMP LC: The role of sympathetic nervous activity in chronic renal failure. J Clin Basic Cardiol 4: 179-182, 2001.

SATA Y, SCHLAICH MP: The potential role of catheter-based renal sympathetic denervation in chronic and end-stage kidney disease. J Cardiovasc Pharmacol Ther 2016: 344-352, 2016.

SEDAGHAT G, GARDNER RT, KABIR MM, GHAFOORI E, HABECKER BA, TERESHCHENKO LG: Correlation between the high-frequency content of the QRS on murine surface electrocardiogram and the sympathetic nerves density in left ventricle after myocardial infarction: Experimental study. J Electrocardiol 50: 323-331, 2017.

SHIMAMURA T, MORRISON AB: A progressive glomerulosclerosis occurring in partial five-sixths nephrectomized rats. Am J Pathol 79: 95-106, 1975.

SINGH S: Cardiovascular disease in chronic kidney disease. Clin Quer Nephrol 3: 20-29, 2014.

SMEETS B, KUPPE C, SICKING EM, FUSS A, JIRAK P, VAN KUPPEVELT TH, ENDLICH K, WETZELS JF, GRÖNE HJ, FLOEGE J, MOELLER MJ: Parietal epithelial cells participate in the formation of sclerotic lesions in focal segmental glomerulosclerosis. J Am Soc Nephrol 22: 1262-1274, 2011.

ŠVÍGLEROVÁ J, KUNCOVÁ J, NALOS L, TONAR Z, RAJDL D, ŠTENGL M: Cardiovascular parameters in rat model of chronic renal failure induced by subtotal nephrectomy. Physiol Res $\mathbf{5 9}$ (Suppl 1): S81-S88, 2010.

TUDORANCEA I, LOHMEIER TE, ALEXANDER BT, PIEPTU D, SERBAN DN, ILIESCU R: Reduced renal mass, salt-sensitive hypertension is resistant to renal denervation. Front Physiol 9: 455, 2018.

VANĚČKOVÁ I, HOJNÁ S, KADLECOVÁ M, VERNEROVÁ Z, KOPKAN L, ČERVENKA L, ZICHA J: Renoprotective effects of ET(A) receptor antagonists therapy in experimental non-diabetic chronic kidney disease: Is there still hope for the future? Physiol Res 67: 55-67, 2018.

WANG SJ, LIAO KK, LIOU HH, LEE SS, TSAI CP, LIN KP, KAO KP, WU ZA: Sympathetic skin response and R-R interval variation in chronic uremic patients. Muscle Nerve 17: 411-418, 1994.

YANG CC, CHEN YT, WALLACE CG, CHEN KH, CHENG BC, SUNG PH, LI YC, KO SF, CHANG HW, YIP HK: Early administration of empagliflozin preserved heart function in cardiorenal syndrome in rat. Biomed Pharmacother 109: 658-670, 2019. 